\title{
PELAYANAN PLKB (PENYULUH LAPANGAN KELUARGA BERENCANA) DI KECAMATAN TANJUNG SENENG KOTA BANDAR LAMPUNG
}

\author{
Rosidah, S.Sos.,M.Si \\ idahros40@gmail.com \\ Program Studi Administrasi Publik, Fakultas Ilmu Sosial dan Ilmu Politik, UTB Lampung
}

\begin{abstract}
ABSTRAK
Tujuan pelayanan KB adalah meningkatkan jumlah peserta KB atas kesadaran dan tanggung jawab, membina peserta KB aktif dalam rangka kelembagaan dan pembudayaan NKKBS, mencapai sasaran penurunan tingkat kelahiran dan menngkatkan menciptakan Keluarga kecil sejahtera melalui mengendalian pertumbuhan penduduk.

Penelitian tentang upaya peningkatan pelayanan Penyuluh Lapangan Keluarga berencana (PLKB) berupa Faktor - faktor penghambat peningkatan pelayanan Penyluh Lapangan Keuarga Berencana (PLKB) berupa kurangnya informasi kepada calon peserta KB ,sarana dan prasaranan pendukung penyuluhan yang kurang memadai serta tingkat pengetahuan masyarakat terhadap program Keluarga Berencana. Penyampaian informasi tentang KB dan melakukan edukasi mengenai program Keluarga Berencana serta penggunaan alat kontrasepsi kepada Pasangan Usia Subur yang ada di Kecamatan Tanjung Seneng dengan menggunakan sarana komunikasi langsung atau komunikasi tatap muka dengan membuat acara penyuluhan yang dibuat dengan acara yang sesuai dengan minat masyarakat setempat agar lebih dapat menarik minat serta perhatian dari pasangan usia subur di kecamatan Tanjung Seneng.
\end{abstract}

Kata Kunci: Keluarga Berencana ( KB )

\section{PENDAHULUAN}

Semakin tinggi pertumbuhan penduduk maka akan semakin besar usaha yang harus dilakukan pemerintah untuk mempertahankan kesejahteraan rakyat. Selain itu, masalah lain yang muncul juga meliputi beberapa aspek kehidupan lainnya seperti kesempatan pendidikan, kesempatan untuk bekerja, dan kesehatan,sehingga pemerintahmulai mencari jalan keluar untuk menekan dan mengendalikan laju pertambahan penduduk Indonesia di masa mendatang, salah satunya dengan program Keluarga Berencana.
Keluarga Berencana (KB) merupakan salah satu pelayanan kesehatan preventif yang paling dasar dan utama bagi wanita maupun pria. Orang yang menggunakan $\mathrm{KB}$ disebut sebagai akseptor. KB merupakan upaya peningkatan kepedulian dan peran serta masyarakat melalui pendewasaan usia perkawinan, pengaturan kelahiran, pembinaan ketahanan keluarga, dan peningkatan kesejahteraan keluarga guna mewujudkan keluarga kecil, bahagia dan sejahtera (Arum et al, 2009 dalam Anggraini dan Martini).

KB juga merupakan salah satu cara yang efektif dalam menolong istri menghindari kehamilan resiko tinggi 
seperti kehamilan dengan rentang usia yang berdekatan (kurang dari dua tahun), kehamilan pada usia ibu yang terlalu tua, kehamilan pada usia ibu yang terlalu muda serta kehamilan yang terjadi pada istri yang sudah memiliki anak lebih dari empat. Program peningkatan dan pelayanan KB mungkin tidak menjamin kesehatan ibu dan anak secara langsung, tetapi dapat melindungi keluarga terhadap kehamilan risiko tinggi, yang diakibatkan oleh masalah-masalah kesehatan seperti hipertensi, diabetes mellitus, anemia dan penyakit-penyakit kronis lainnya yang dapat berpengaruh terhadap kehamilan serta dapat mengakibatkan cacat bawaan atau kelainan genetik pada anak.

Program Keluarga Berencana adalah program yang dikeluarkan pemerintah dalam rangka mengendalikan pertumbuhan dan angka kelahiran penduduk, hal ini dilakukan untuk kesejahteraan keluarga Indonesia, yang sangat bermanfaat untuk peningkatan kualitas di generasi Negara Indonesia mendatang. Program Keluarga Berencana yang dikeluarkan pemerintah ini merupakan suatu upaya pemerintah dalam melakukan pembangunan bagi Negara Indonesia. pembangunan tersebut adalah sebuah hubungan yang saling berkaitan dalam rangka melakukan pengarahan, mengendalikan, dan juga mewujudkan setiap bentuk perubahan yang mengarah kepada kebutuhan masyarakat. batasan ini, tidak setiap perubahan yang terjadi dapat disebut pembangunan, hal ini dikarenakan sebuah pembangunan belum tentu menghasilkan perubahan sesuai dengan apa yang diinginkan. Sebaliknya perubahan yang telah direncanakan secara sistematis merupakan kegiatan pembangunan.

Keberhasilan pembangunan yang dilakukan pemerintah dalam Program Keluarga Berencana tidak dapat dilepaskan keberhasilannya dari adanya peranan Petugas Lapangan Penyuluh Keluarga Berencana (PLKB). Undang-undang No.10 Tahun 1992 tentang perkembangan Kependudukan dan Pembangunan keluarga Sejahtera mengamanatkan pada Bab VII pasal 24 ayat (1) setiap penduduk mempunyai hak dan kesempatan yang seluas luasnya dalam berperan serta dalam upaya Perkembangan Kependudukan dan Pembangunan Keluarga Sejahtera, dan hal ini dipertegas kembali dalam ayat ke (2) yakni, peran serta yang dimaksudkan adalah dapat dilakukan melalui Lembaga Swadaya dan Organisasi Masyarakat, pihak Swasta dan perorangan, secara sukarela, dan mandiri serta sesuai dengan kemampuan masing masing.

Pasca otonomi daerah muncul, tahun 2004 fenomena pelaksanaan program Nasional keluarga Berencana dalam sebagian kewenangan bidang keluarga berencana (KB) dan Keluarga Sejahtera (KS) diserahkan kepada Pemerintah Kab/Kota, berdasarkan Keputusan Presiden No. 103 tahun 2001 tentang kedudukan Tugas, fungsi kewenangan susunan Organisasi dan Tata Kerja Lembaga Pemerintah Non Departemen, kemudian diubah lagi beberapa kali dan yang terakhir adalah Keputusan Presiden 
No. 64 tahun 2005 yakni penyerahan sebagian bidang Keluarga Berencana dan Keluarga Sejahtera ini membawa suatu perubahann dalam pengelolaan program Keluarga Berencana Nasional di daerah Otonomi. Yang dulunya, urusan Keluarga Berencana terpusat dan dikoordinasikan oleh Badan Keluarga Kecil Berencana Nasional (BKKBN), sekarang menjadi salah satu dan kewenangan daerah otonomi, Kabupaten, atau Kota. Selain itu jika dulunya secara hirarki terdapat suatu lembaga khusus BKKBN di level pemerintah Kabupaten atau Kotamadya, kini diurus oleh Badan atau Kantor yang satuan kerja pengelola daerah program Keluarga Berencana yang bermacam macam, sehingga dapat menangani 2 sampai 3 bidang, sehingga tidak lagi dapat memusatkan konsentrasinya dalam menangani program Keluarga Berencana.

Tujuan pelayanan KB adalah meningkatkan jumlah peserta $\mathrm{KB}$ atas kesadaran dan tanggung jawab, membina peserta KB aktif dalam rangka kelembagaan dan pembudayaan NKKBS, mencapai sasaran penurunan tingkat kelahiran dan menngkatkan menciptakan Keluarga kecil sejahtera melalui mengendalian pertumbuhan penduduk.

Pencapaian tujuan pelayanan KB di Provinsi Lampung berpatokan pada kebijakan dan strategi yang terdiri atas :

1. Pengambilan kebijakan yang di arahkan untuk lebih meningkatkan kualitas dan kuantitas pelayanan maupun pemakaian alat kontrasepsi yang mandiri.
2. Dalam memberikan pelayanan $\mathrm{KB}$ kepada Masyarakat di anut pola pelayanan kontasepsi rasional dengan memperhatikan golongan usia di bawah 20 tahun. Usia 20 - 30 tahun, usia di atas 30 tahun dan PUS yang sudah tidak ingin anak lagi.

3. Pelayanan kontrasepsi ditujukan dan diarahkan kepada pemakaian metode yang efektif.

4. Mengusahakan pemerataan tempat dan tenaga pelayanan kontrasepsi baik dari unsur pemerintah maupun swasta.

5. Mendekatkan pelayanan kepada sasaran dengan memperhatikan situasi dan kondisi masyarakat.

6. Memberikan rujukan kepada aseptor KB yang mengalami gangguan komplikasi karena alat kontrasepsi $\mathrm{KB}$.

Pelayanan KB merupakan salah satu bagian dalam paket Pelayanan Kesehatan Reproduksi yang perlu mendapatkan perhatian yang serius, karena dengan mutu pelayanan KB yang berkualitas, diharapkan akan dapat meningkatkan tingkat kesehatan dan kesejahteraan. program KB sangat berperan untuk menekan angka kelahiran di Indonesia serta menurunkan tingkat kematian ibu saat persalinan. Selain itu, KB bertujuan untuk memperhatikan beberapa kepentingan antara lain adalah kepentingan orangtua, kepentingan anakanak dan kepentingan masyarakat. Orangtua diharapkan mengetahui batasbatas kemampuannya dalam mengurus kebutuhan anak-anaknya sampai menjadi orang yang berguna karena orangtua 
adalah orang yang paling bertanggung jawab atas keselamatan dirinya dan keluarganya (anak-anak). Disamping kepentingan orangtua juga terdapat kepentingan anak-anak, anak merupakan amanah dan karunia Tuhan yang harus dijunjung tinggi sebagai pemberian yang tidak ternilai harganya. Maka mengatur kelahiran merupakan salah satu cara dalam menghargai kepentingan anakanak. Terakhir adalah kepentingan masyarakat, masyarakat mengharapkan agar setiap orangtua sebagai kepala keluarga memelihara dengan baik keluarga dan anak-anaknya sehingga anak-anak mereka kelak dapat menjadi anggota masyarakat yang berguna bagi orangtua dan bangsa. Dengan demikian keluarga diharapkan dapat membantu terlaksananya kesejahteraan seluruh masyarakat. Tanpa bantuan dan kesungguhan keluarga-keluarga dalam usaha penurunan pertambahan penduduk yang cepat, pembangunan tidak berarti (Mochtar, 1992). Hal ini berarti KB menjadi hal yang penting bagi akseptor KB untuk menunda kehamilan dengan menggunakan alat kontrasepsi.

\section{METODE}

Tipe penelitian yang digunakan adalah tipe Kualitatif deskriptif yang dimaksudkan untuk memberikan gambaran secara jelas mengenai masalah-masalah yang diteliti, menginterpretasikan serta menjelaskan data secara sistematis. Dasar penelitian ini adalah survey, yaitu pembagian kuesioner kepada responden yang berisi pertanyaan-pertanyaan mengenai hal yang berhubungan dengan penelitian yaitu mengenai Pelayanan PLKB (Penyuluh Lapangan Keluarga Berencana) di Kecamatan Tanjung Seneng Kota Bandar Lampung.

\section{ANALISIS HASIL DAN PEMBAHASAN}

Pelaksanaan Penelitian ini dituangkan dalam bentuk wawancara danangket. Wawancara dilakukan kepada penyuluh KB, Tokoh Masyarakat, dan Akseptor KB. Materi Wawancara terdiri atas Program Kerja Penyuluh Keluarga Berencana, upaya yang telah dan akan dilakukan oleh Penyuluh, Keberadaan penyuluh dan perhatin masyarakat terhadap keberadaaan penyuluh KB.

1. Wawancara dengan Sri Wahyuni, S.Sos., MM. (pengawas PLKB Kecamatan Tanjung Seneng).

Berapa banyak tenaga penyuluh KB di Kecamatan Tanjung Seneng, ada berapa kelompok KB di Kecamatan Tanjung seneng, dan bagaimana dukungan masyarakat terhadap Tenaga PLKB dan sarana dan metode apa yang digunakan untuk melakukan kegiatan penyuluhan dan apa yang sudah dilakukan dan yang belum dilakukan oleh penyuluh KB?

... PLKB di Kecamatan Tanjung Seneng berjumkah 4 tenaga penyuluh yang tersebar ke dalam 4 kelurahan. dukungan masyarakat terhadap program PLKB di Kecamatan Tanjung Seneng cukup baik dengan adanya peningkatan 
akseptor KB dari tahun sebelumnya. Metode yang digunakan dalam penyuluhan berupa advokas dan simulasi tentang macam-macam alat kontrasepsi dan kegunaannya. Banyak hal yang telah dilakukan penyuluh sesuai dengan program kerja. Hal yang belum kami lakukan adalah dikusi dengan tokoh agama tentang program KB menurut kaidah Agama.

2. Wawancara dengan Hi. Achyar (Tokoh Masyarakat Setempat). Bagaimana menurut Bapak tentang Penyuluh KB ?

... menurut saya program keluarga berencana di Kecamatan Tanjung seneng sudah cukup bagus. Masyarakat pada umumnya khususnya ibu-ibu kelompok pengajiian banyak yang ikut serta mengikuti dan menyimak keterangan penyuluh.

Hasil wawancara dengan penyuluh lapangan dituangkan dalam bentuk program kerja penyuluh lapangan Keluarga Berencana Kecamatan Tanjung Seneng. Berdasarkan tugas, fungsi $\mathrm{PKB} / \mathrm{PLKB}$ telah tergambar bahwa $\mathrm{PKB} / \mathrm{PLKB}$ harus melakukan prosedur kerja PKB/PLKB secara tepat, efektif, efisien dalam mencapai tujuan yang telah ditetapkan. Mekanisme kerja $\mathrm{PKB} / \mathrm{PLKB}$ dalam penggarapan program merupakan acuan, prosedur kerja PKB/PLKB dalam melaksanakan berbagai kegiatan operasional ditingkat lini lapangan, tetapi juga berguna sebagai pedoman Kab/Kota, Provinsi terutama terkait dengan pembinaan, orientasi serta penilaian dalam pelaksanaan tugas. Mekanisme kerja PKB/PLKB dalam penggarapan program apabila dilaksanakan dengan sungguh-sungguh dan secara sistematis akan memberikan sumbangan yang sangat besar terhadap keberhasilan pelaksanaan operasional program Kependudukan dan KB ditingkat lini lapangan. Mekanisme kerja PKB/PLKB di era otonomi daerah adalah sebagai berikut :

1. Pendekatan Tokoh Formal

2. Pendataan dan Pemetaan

3. Pendekatan Tokoh Informal

4. Pembentukan Kesepakatan

5. Penegasan Kesepakatan

6. Penerangan dan Motivasi

7. Penteladanan/Pembentukan Pelopor

8. Pelayanan $\mathrm{KB}$

9. Pembinaan

10. Pencatatan, Pelaporan dan Evaluasi

Dari sepuluh langkah mekanisme kerja PKB/PLKB di atas akan diklasifikasikan menjadi empat tahapan sesuai dengan proses manajemen POAC (Planning, Organizing, Actuating,Controling). Berikut akan diuraikan mekanisme kerja PKB/PLKB mengikuti tahapan pada proses manajemen POAC tersebut: Penyiapan Dukungan (data, tokoh formal dan informal). Penyiapan dukungan merupakan rangkaian kegiatan merancang berbagai kegiatan program yang akan dilakukan secara bersamasama dalam rangka mencapai tujuan yang telah ditetapkan, dalam tahapan ini bagaimana seorang PKB/PLKB harus mampu mencari dan mengenali wilayahnya serta kemampuan untuk 
melakukan pendekatan dengan tokohtokoh yang ada di wilayahnya baik tokoh formal maupun tokoh informal, tahapan penyiapan ini bisa dikatakan sebagai tahapan perencanaan sebagai langkah awal dari proses mekanisme kerja meliputi :

\section{Pendekatan Tokoh Formal;}

Pendekatan Tokoh Formal adalah merupakan langkah awal yang harus dilakukan oleh PKB/PLKB dalam suatu daerah baru atau dalam mengembangkan kegiatan baru adalah menghadap Kepala Desa/Lurah untuk melaporkan kehadirannya di Desa, berbagi wawasan (share vision) Program Kependudukan dan KB sebagai program Pemerintah, memohon dukungan, serta izin untuk melakukan pendataan dan pemetaan bersama kader IMP (PPKBD, Sub PPKBD dan Kelompok kegiatan) di wilayah kerjanya yang baru. PKB/PLKB kemudian melakukan kunjungan kepada para Tokoh-tokoh Formal lain di wilayah kerjanya yang terdiri pada Petugas tingkat Desa/Kelurahan, seperti Bidan Desa, Petugas Agama, Petugas Penerangan dan lain-lain. Pendekatan tokoh formal ini harus dimanfaatkan untuk menyampaikan informasi, berkonsultasi, meminta izin, meminta dukungan dan menyiapkan kesepakatan dengan penggarapan program Kependudukan dan KB di wilayah kerja masing-masing. Maksud dan Tujuan dari kegiatan ini adalah untuk mendapat dukungan baik politis maupun pelaksanaan sesuai dengan peran dan fungsi masing-masing dengan penuh rasa tanggung jawab berdasarkan rencana yang telah disepakati. Adapun sasarannya adalah : Kepala desa/lurah, perangkat desa/kelurahan, ketua RW, Babinsa, Babinmaspol, ketua LMD, TNI, Polri, dan sebagainya. Kegiatan dilakukan melalui : Kunjungan rumah, pertemuan perorangan, pertemuan kelompok baik yang bersifat resmi maupun tidak resmi. Tempat Pendekatan tokoh formal dapat dilakukan di mana saja sesuai kebutuhan, misalnya di kantor, di rumah, pada waktu pertemuan, baik waktu pagi, sore hari ataupun malam.

2. Pendataan dan pemetaan; Pendataan dan pemetaan adalah Suatu proses kegiatan pengumpulan, pencatatan, pengolahan, penganalisaan dan penyajian data. Untuk mengenali wilayah kerjanya, PKB/PLKB perlu melakukan pengenalan wilayah, mencakup batas wilayah, data kependudukan, data KB dan data yang relevan dengan kegiatan baru yang akan dikembangkan (misalnya $\mathrm{BKB}, \mathrm{BKR}, \mathrm{BKL}$ ) terutama tokoh formal terkait dan tokoh informal di masing-masing RW/RT. Hasil pendataan kemudian di petakan sebagai dasar kegiatan operasional ke depan. Pengumpulan data harus dilakukan secara benar dan lengkap. Kemudian diolah dan disajikan, 
dengan cara dan bentuk yang mudah dimengerti. Salah satu cara penyajiannya adalah dalam bentuk Peta Dinamis, dibantu oleh tabel dan grafik lainnya. Maksud dan Tujuan adalah untuk Menguasai secara jelas dan rinci situasi wilayah kerjanya sebagai bahan untuk penyusunan rencana kerja, penggarapan program kependudukan dan $\mathrm{KB}$, penilaian program serta untuk mengetahui faktor pendukung dan penghambat pelaksanaan program.

\section{Pendekatan Tokoh Informal;} Pendekatan Tokoh Informal adalah Suatu kegiatan untuk menciptakan hubungan kerja antara PKB/PLKB dengan tokoh-tokoh informal yang ada di tingkat desa, sehingga mereka berperan aktif dan mendukung pelaksanaan program. Pendekatan dilakukan untuk menjelaskan manfaat program bagi masyarakat, pentingnya para tokoh berperan dalam program, serta meminta dukungan dan para tokoh mau mengajak panutannya untuk peduli dan berperan serta dalam program ini.

\section{Pembentukan}

Kesepakatan;

Kegiatan ini merupakan suatu proses yang dilakukan secara sistematis untuk mencapai kesepakatan politis dan teknis penggarapan program kependudukan dan KB Kepala Desa/Lurah mengundang para tokoh baik yang telah menyatakan kesediaannya dan yang masih ragu untuk mendukung program dalam Musyawarah Masyarakat Desa dengan tujuan untuk mengajak para tokoh berpartisipasi secara aktif.
5. Penegasan Kesepakatan; Proses untuk memantapkan tokoh formal dan informal agar berperan aktif sesuai dengan hasil kesepakatan dan rencana yang telah diputuskan dalam rakor desa.

6. Penerangan dan motivasi; Merupakan salah satu kegiatan pokok dalam program Kependudukan dan KB agar masyarakat mengetahui, mengerti dan akhirnya mau melaksanakan program kependudukan dan KB.

7. Pembentukan grup pelopor penggerakan; Adalah langkah untuk mengajak/ mempersiapkan seseorang atau kelompok untuk menarik/ menggerakkan anggota masyarakat lainnya, baik untuk menjadi peserta $\mathrm{KB}$, dalam memilih alat kontrasepsi (khususnya yang lebih efektif) maupun dalam menjadi peserta pengelola program.

8. Pelayanan; adalah Suatu porses kegiatan yang dilakukan oleh PLKB/PKB dalam mempersiapkan pelayanan teknis kepada sasaran sesuai dengan jenis pelayanan yang diberikan, misalnya pelayanan kontrasepsi kepada calon peserta $\mathrm{KB}$, analisa data kependudukan dan pembentukan serta pembinaan $\mathrm{BKB}, \mathrm{BKR}, \mathrm{BKL}$ dan UPPKS. Bekerjasama dengan Petugas Medis, Agama, Guru dan unsur terkait.

9. Peserta KB; kegiatan dalam tahapan ini adalah kegiatan mengayomi, membimbing, mengarahkan dan mengaktifkan peserta KB, pelaksana, pengelola IMP sehingga meningkatkan kesertaan ber-KB.

10. Pencatatan, Pelaporan dan Evaluasi ; Pencatatan adalah suatu 
kegiatan mencatat hal-hal yang berkaitan dengan masukan, proses maupun hasil kegiatan yang telah dilakukan, pencatatan ini terutama dilakukan untuk hal-hal yang bersifat kuantitatif dengan menggunakan form yang telah ditentukan di samping halhal yang bersifat kualitatif. Pelaporan adalah suatu kegiatan melaporkan halhal yang telah dicatat di atas. Untuk data yang bersifat kuantitatif dilaporkan dengan menggunakan formulir yang telah ditentukan. Untuk hal-hal yang bersifat kualitatif, selain dapat dilaporkan secara lisan melalui forum yang ada seperti staff meeting, rakor atau konsultasi dan lain-lain. Evaluasi adalah kegiatan penilaian dari seluruh kegiatan yang telah dilakukan berikut hasil-hasilnya sebagai bahan penyusunan rencana kegiatan selanjutnya. Hasil Rekapitulasi jawaban angket akseptor KB adalah sebagai berikut:

Table 1.

Tabel Angket

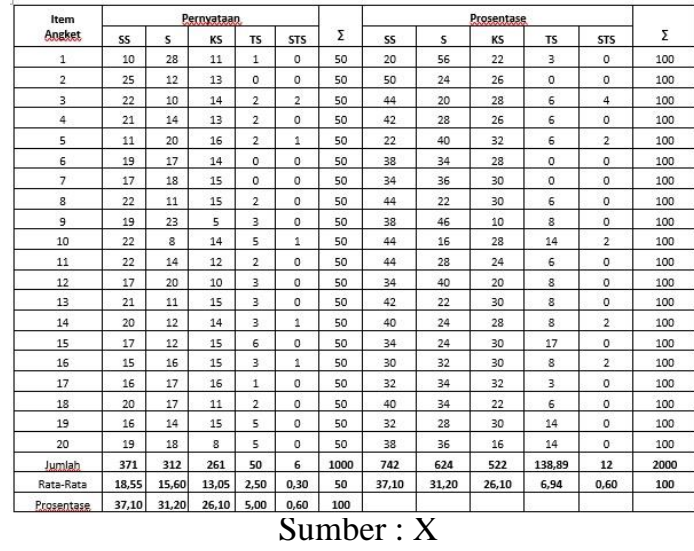

Berdasarkan data di atas dapat ditarik kesimpulan bahwa sebanyak 18,5 (37,10\%) akseptor sangat setuju pelayanan $\mathrm{KB}$ yang telah diberikan oleh penyuluh, 15,6 $(32,20 \%)$ akseptor setuju dengan pelayanan penyuluh $\mathrm{KB}$, sebanyak 13 akseptor (26\%) kurang setuju dengan pelayanan penyuluh keluarga berencana dan sisanya sebanyak 2,5 akspetor tidak setuju dengan pelayanan penyuluh KB. Dari hasil data tersebut dapat ditarik suatu kesimpulan bahwa terjadi peningkatan pelayanan penyuluh $\mathrm{KB}$ rata - rata sebesar 34 persen yang diperoleh dari jawaban sangat setuju dan setuju yang diberikan oleh responden.

\section{PENUTUP}

Hasil penelitian ini dapat disimpulkan bahwa, adanya peningkatan pelayanan penyuluh KB. Untuk Penyampaian informasi tentang $\mathrm{KB}$ dan melakukan edukasi mengenai program Keluarga Berencana serta penggunaan alat kontrasepsi kepada Pasangan Usia Subur yang ada di Kecamatan Tanjung Seneng dengan menggunakan sarana komunikasi langsung atau komunikasi tatap muka dengan membuat acara penyuluhan yang dibuat dengan acara yang sesuai dengan minat masyarakat setempat agar lebih dapat menarik minat serta perhatian dari pasangan usia subur di kecamatan Tanjung Seneng.

\section{DAFTAR BUKU}

BKKBN. 2002. Pedoman Kerja PLKB dalam Menghadapi Perubahan. Jakarta: BKKBN.

Badan Koordinasi Keluarga Berencana Nasional. ( 2007 ). Materi KIE 
Keluarga Berencana, Bagi Penyuluh KB: Buku Pedoman Materi KIE. Jakarta: Direktorat Advokasi dan KIE, Badan Koordinasi Keluarga Berencana Nasional.

Badan Koordinasi Keluarga Berencana Nasional. (2006). Arah Kebijakan Program KBNasional Tahun 20052009 dan Refleksi Dua Tahun Pelaksanaan Program KBDalam Era Desentrallisasi: Jakarta: Direktorat Pelayanan Informasi dan Dokumentasi, Badan Koordinasi Keluarga Berencana Nasional.

Baziad, A. 2002. Kontrasepsi Hormonal. Jakarta : PT Bina Pustaka Sarwono

Darwin, Muhajir, 1996 Kesehatan Reproduksi: Ruang Lingkup dan Kompleksitas, Masalah dalam Majalah Populasi No.7. Tahun 1996, PPK Universitas Gajahmada, Yogyakarta.

Prawirohardjo Baziad, A. 2008. Kontrasepsi Hormonal. Jakarta : PT Bina Pustaka

Sarwono Prawirohardjo Depkes RI. 2008. Profil Kesehatan Indonesia 2007. Jakarta : Departemen Kesehatan Republik Indonesia

Glasier \& Gebbie. 2006. Keluarga Berencana dan Kesehatan Reproduksi. Jakarta :

EGC Hidayat, A. 2010. Metode Penelitian Kebidanan dan Teknik Analisis Data. Jakarta : Salemba Medika

Meilani, dkk. 2010. Pelayanan Keluarga Berencana. Yogyakarta : Fitramaya 